ferrous compound, probably the hydroxide, which is gradually oxidized to the black oxide as air penetrates to the tissues. Although as yet supported by no direct evidence, this theory fits not only the facts established in the present work but also a number of hitherto unrelated observations of other workers in the same field, such as that of Tinckler' that the black pigmentation was induced in normal potatoes by contact with rusting iron during boiling, and the evidence obtained by Ross and Tottingham ${ }^{2}$ that the proteins of blackening potatoes are more easily hydrolysable and autolysable than those of normal tubers.

I should like to thank Prof. V. H. Blackman for his advice and criticism throughout the course of this work.

Ursula M. Robison.

Research Institute of Plant Physiology,

Imperial College of Science and Technology,

South Kensington, S.W.7. June. 2 .

'Biochem. J., 25, 773 (1931).
2 J. Agric. Res., 57, 453 (1938).

\section{Plagiophyres in an Intrusion at Downpatrick}

IN 1937 B. C. King ${ }^{1}$, in a petrographical examination of some Caledonian hypabyssal rocks from Kirkcudbrightshire, recorded the occurrence of plagiophyres in the dyke assemblage of this area.

Recent examination of a small intrusion at Slievenagriddle, two miles east of Downpatrick in Northern Ireland, has resulted in the discovery of this rocktype in the hypabyssal phase of the Newry 'granite' mass. The intrusion was originally recorded by the Geological Survey of Ireland ${ }^{2}$, and on macroscopic examination was described by the Survey as syenite. In thin section the rock is seen to correspond closely to the Scottish plagiophyres; mafic minerals being entirely represented by chlorite, felspar and albiteoligoclase, abundant secondary calcite, etc.

Dykes of this Irish suite have been described from the Ards Peninsula ${ }^{3}$ and the Killough-Ardglass coast ${ }^{4}$, and are dominantly lamprophyric in these two areas. It is probable that further examination of this dykeswarm towards the south-west (and the Newry 'granite') will reveal a more extensive variety of rock types than are at present known from the County Down area.

Department of Geology.

Edward M. Patterson.

Queen's University, Belfast.

'lKing, B. C., Proc. Geol. Assoc., 48, 282-306 (1937).

Mem. Geol. Surv. Ireland, Sheets 49,50,61, pp. 15 and 47.

JReynolds, D. L., Geol. Mag., 63, 97-111 and 145-165.

Tomkeieff, S. I., and Marshall, C. E., Quart. J. Geol. Soc., 96, 321338.

\section{Specific Heat of $\beta$-Brass}

Mx previous theoretical work ${ }^{1}$, based on a method of approximation, has been criticized by Bethe and Kirkwood ${ }^{2}$. I have now carried out a rigorous evaluation of the partition function at constant volume, starting first with the two dimensional quadratic lattice.

Three partition functions are calculated succes- sively, namely, $P(1), P(n)$ and $P\left(n^{2}\right)$ which refer to : a square of four atoms, the 'elementary cell'; a ladder consisting of $n$ elementary cells joining in one dimension; and the whole lattice, which consists of $n$ ladders joined together with their lath.

$P(1)$ is a sum of eight terms according to the eight possible configurations of the cell. In order to account for the statistical correlations of the cells (the long. range order effect), the terms of $P(1)$ are considered to be the coefficients of a certain quadratic form in two variables and $P(n)$ to be the $n$-fold iterated quadratic form. Similarly, the terms of $P(n)$ are considered to be the coefficients of a quadratic form in $2^{n}$ variables and the $n$-fold iterated form to be equal to $P\left(n^{2}\right)$. In these calculations the form in a large number of variables is reduced to a product of forms in two variables.

In the limit, $n \rightarrow \infty, P\left(n^{2}\right)$ is found to be equal to $[p(x, y)]^{n^{3}}$ where $y=x=\exp (-\varphi / k \mathrm{~T})$ and $\varphi$ is a constant of the dimension of an energy. The mean energy is equal to $\varphi y \partial \log p / \partial y$. The function $p(x, y)$ has the following form :

$$
\begin{aligned}
& p(x, y)=\frac{1}{2}\left\{( 1 + y ) \left[\left(1-x^{2}\right)^{2}+8 x^{2}(1+y)+\right.\right. \\
& \left.\left(1-x^{2}\right) \sqrt{1+14 x^{2}+x^{4}}\right]+\sqrt{2}\left[\left(1-x^{2}\right)^{4}(1-y)^{2}+\right. \\
& 32 x^{4}\left(1+14 y^{2}+y^{4}\right)+8 x^{2}\left(1-x^{2}\right)^{2}\left(2-3 y+8 y^{2}+\right. \\
& \left.y^{3}\right)+\left(\left(1-x^{2}\right)^{3}(1-y)^{2}+8 x^{2}\left(1-x^{2}\right)(1-\right. \\
& \left.\left.\left.y+7 y^{2}+y^{3}\right)\right) \sqrt{1+14 x^{2}+x^{4}}\right]^{1 / 2} \cdot\left[\left(1+14 x^{2}+\right.\right. \\
& \left.\left.x^{4}\right)+\left(1-x^{2}\right) \sqrt{1+14 x^{2}+x^{4}}\right]^{-1} .
\end{aligned}
$$

It is independent of $n$ and has no singularity. The specific heat curve has a broad maximum which has no resemblance to a $\lambda$-point.

The method applies to a lattice in three dimensions, and calculations are in progress.

Davy Faraday Laboratory,

Albemarle Street,

London, W.1.

May 28.

${ }^{2}$ Proc. Roy. Soc., A, 168, 546 (1938).

${ }^{2} J$. Chem. Phys., 7, 578 (1939).

R. Fisenschitz.

\section{Metallic Triazine Complexes}

IN a recent note $^{1}$ referring to the palladium derivatives of diazoaminobenzene and of $4: 4^{\prime}$. dimethyl-diazoaminobenzene described by Dwyer ${ }^{2}$, it was stated that these compounds, containing one palladium atom united to three diazoaminobenzene units, "appear to be the first examples of hexacovalent palladous compounds [to be] described", this statement being made also by Dwyer in his original paper.

Actually, however, I have described the first such compounds', having prepared both platinous and palladous salts of $\alpha \beta \gamma$-triamino-propane, the palla. dous derivative having the formula

$$
\left[\left\{\mathrm{NH}_{2} \mathrm{CH}_{2} \mathrm{CH}\left(\mathrm{NH}_{2}\right) \mathrm{CH}_{2} \mathrm{NH}_{2}\right\}_{2} \mathrm{Pd}\right] \mathrm{I}_{2} \text {. }
$$

Evidence was adduced to show that in such compounds all the amino-groups were co-ordinated to the metal, which was therefore undoubtedly hexacovalent.

Apart from this certain case, it is probable that the black crystalline compound ${ }^{4}$ of empirical formula $\left(\mathrm{NH}_{3}\right)_{2} \mathrm{PdCl}_{3}$ has the constitution shown, containing one hexacovalent palladous and one hexacovalent palladic atom, bridged by the two chlorine atoms ${ }^{5}$. In this case the compound would exist as a resonance 